\title{
Digitalization of the processes in the housing and utility sector in the context of the «Smart City» concept
}

\author{
Nadezhda Anisimova ${ }^{1, *}$, Tatiana Narolina ${ }^{1}$, Tatiana Smotrova ${ }^{1,2}$, and Vitaliy Popov ${ }^{1,2}$ \\ ${ }^{1}$ Voronezh State Technical University, 20 letiya Oktyabrya street, 84,Voronezh, 394006, Russia \\ ${ }^{2}$ Voronezh State University, Universitetskaya sq., 1, Voronezh, 394045, Russia
}

\begin{abstract}
One of the most important and promising areas of digitalization is to create favorable environment for the population of cities and improve the quality of housing and communal services. "Smart City" concept implemented in many countries provides solutions for this problem. However, the analysis of examples of the implementation of such initiatives indicates that the housing and utilities sector is represented in Russia by a limited number of projects, in particular, the problem of controlling the timing and quality of work in maintaining the housing stock, including the overhaul of residential buildings, remains unresolved. This leads to accidents and does not contribute to creating a comfortable environment for the population. This study is devoted to the analysis of the use of digital technologies in the housing and communal sector and contains recommendations on the creation of an information-analytical system for controlling and monitoring the quality of overhaul repairs of housing.
\end{abstract}

\section{Introduction}

The strategic development priorities of Russia at the present stage correspond to global trends in the use of innovations and digital technologies in order to create favorable and comfortable living conditions for the population in large agglomerations and other settlements. The country has adopted the Strategy for the Development of the Information Society in the Russian Federation for 2017-2030 [1], in accordance with which the "Smart City" [2] concept is being implemented as well as its corresponding federal, regional, and municipal programs [3] to create a single information space to improve the quality of services provided to the population and creating an innovative environment.

Within the context of the above programs, the legal framework is already being formed and pilot projects are being implemented in 37 cities [4], some of which, including Voronezh, have been accepted into the global Association of Smart cities.

The implementation of the Smart City concept requires research and the practical implementation of digital technologies for planning and quality control of housing and communal services, taking into account modern requirements.

\footnotetext{
* Corresponding author: b0lahd@mail.ru
} 


\section{Methodology}

Probabilistic automata [5-17] can model both probabilistic and nondeterministic behavior of systems, which is a slight generalization of MDPs. The verification algorithms for MDPs can be adapted for PAs.

During the study, an analysis and systematization of the implementation of the Smart City project was carried out. Methods of systematic and retrospective analysis made it possible to assess the prerequisites of legislative initiatives and steps taken by the state to develop digitalization in the field of urban and housing and communal services.

The strategic directions of the application of modern information and communication technologies, including the Internet of things (IoT) systems in the housing and communal sector as part of the Smart City project, are investigated.

The possibility of using the methodology for assessing the urban digitalization index "IQ of cities" and the known methods of processing "big data" is considered.

\section{Discussion}

It should be noted that the practice of solving the problem of urban transformation in digitalization is ahead of theory, as experts have not yet developed a general concept, essence, and content of procedures for implementing a unified approach.

As a review of relevant publications $[6-18,21,24]$ on the introduction of information technology in the urban environment, in the city management system and analysis of the practice of the events shows, the emphasis at this stage is on: (i) improving the technological level of the urban environment, (ii) creating an effective urban resources management system and service component (Table 1).

The key components of a smart city [8, 10-23], according to most practitioners, are: urban services, urban facilities, urban infrastructure (transport, education, healthcare, housing and communal services, security, information and communication technologies).

Table 1. The directions for implementation of the Smart city project in the cities of the Russian Federation.

\begin{tabular}{|c|c|}
\hline City & Implemented functional areas of the projects \\
\hline Moscow & $\begin{array}{l}\text { - } \quad \text { city portals, E-services; } \\
\text { - } \quad \text { city wi-fi network and navigation; } \\
\text { - ITS - intellectual training systems; } \\
\text { - } \quad \text { information portals for investors; } \\
\text { - } \quad \text { integrated healthcare informational and analytic system; } \\
\text { - } \quad \text { informational and analytic system for urban development control; } \\
\text { - } \quad \text { environmental monitoring, snow clearing equipment control, smart } \\
\text { energy audit; } \\
\text { - } \quad \text { social monitoring system; }\end{array}$ \\
\hline St.-Petersburg & $\begin{array}{l}\text { - digital city image used as the basis for forecasting and planning of the } \\
\text { city development, } \\
\text { - smart lighting technology systems and outdoor lighting control; } \\
\text { - intelligent transport system based on assessment of transportation } \\
\text { service provision for the population; } \\
-\quad \text { population safety provision system; }\end{array}$ \\
\hline Kazan & $\begin{array}{l}-\quad \text { wireless Internet and situational video surveillance; } \\
-\quad \text { environmental monitoring, smart lighting, smart housing and utility } \\
\text { system; } \\
-\quad \text { city portals, E-services; }\end{array}$ \\
\hline Novosibirsk & - population safety provision system; \\
\hline
\end{tabular}




\begin{tabular}{|l|l|}
\hline & $\begin{array}{l}\text { - city infrastructure control systems for transport, education, healthcare, } \\
\text { housing and utility systems; } \\
-\quad \text { navigation systems for disabled people; }\end{array}$ \\
\hline Samara & $\begin{array}{l}-\quad \text { video surveillance system and population informing about emergencies } \\
\text { with integrated operational command center; } \\
-\quad \text { city infrastructure control systems for transport, education, healthcare, } \\
\text { housing and utility systems, safety; }\end{array}$ \\
\hline Voronezh & $-\quad$ smart lighting system; \\
& $-\quad$ water and heat consumption systems in residential houses; \\
& $-\quad$ transport control systems. \\
\hline
\end{tabular}

At the beginning of 2020, the Ministry of Construction of Russia together with Moscow State University named after Lomonosov presented a procedure for assessing the urban digitalization index "IQ of cities" [25], which is calculated in ten areas (urban management, smart housing and utilities, innovations for the urban environment, smart urban transport, intelligent public and environmental safety systems, tourism and service, intelligent social services systems, economic situation and investment climate, infrastructure of communication networks) and allows of the evaluation of the effectiveness of solutions implemented by cities and regions, participating in the "Smart city" project.

At the same time, during the first calculation of "Smart city", the indicator for 2018 was taken as the base value. The annual assessment of the indicator allows one to evaluate not the index value itself, but the magnitude of its change.

The figure shows the values of indicators for some cities in which the Smart City project is being implemented.

Regarding the housing and utilities sector, as a diversified complex within the urban economy, the analysis revealed that most projects are narrowly focused on collecting information from meters on the consumption of water and other resources without human intervention, organizing and controlling the payment of utility bills online, garbage collection, and some other processes. And this is typical not only for Russian practice. The experience of other countries also indicates that in most cases there is no comprehensive approach to integrating housing and communal services into a single innovative system and information space.

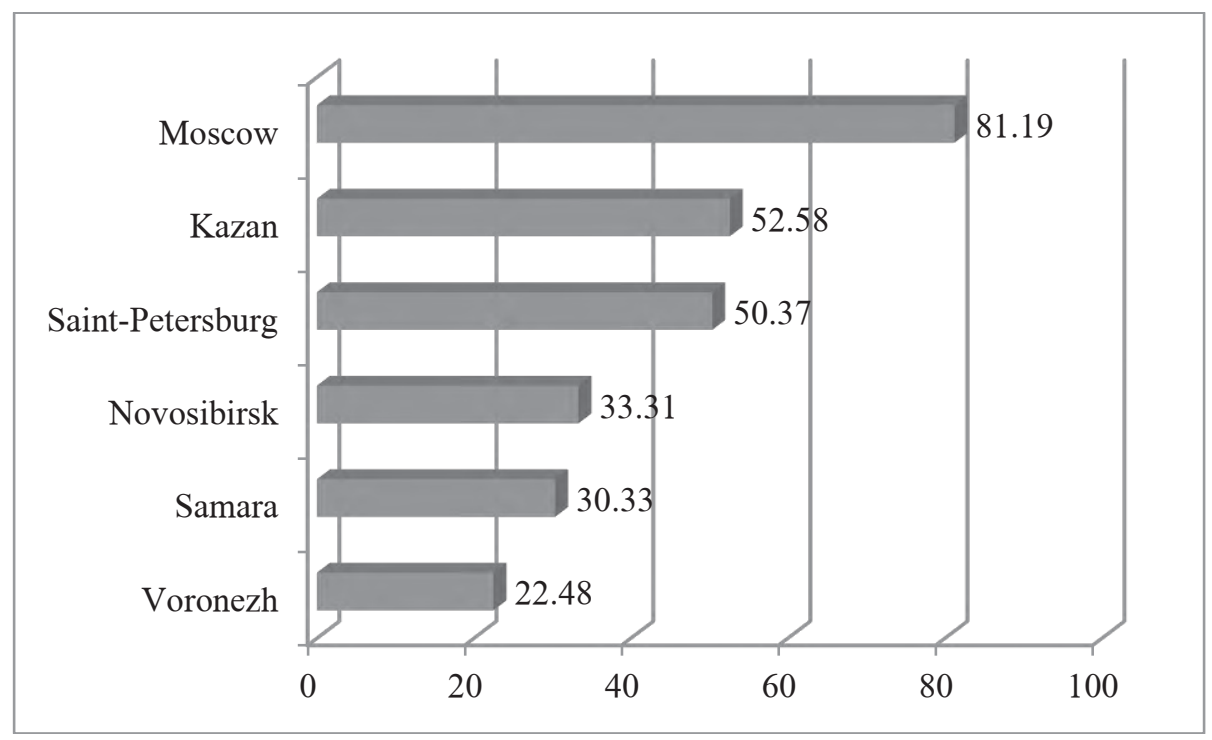

Fig. 1. The values of the cities' digitalization indices. 
Consideration of the housing and utilities system in this format as part of the Smart City concept as a single information space for optimizing city-wide processes and procedures seems limited. At the same time, it is clear that it is not possible to cover the whole set of objects and processes of a diversified housing and communal complex in a limited period of time. The solution to the problem should go, in our opinion, along the path of choosing priority or problematic areas of development or types of services for a particular city. In particular, for most cities, the great problem is the planning, organization, and quality control of capital repairs of the housing stock. An objective reason for the above problems in Russia is the high deterioration of the property complex and the difficulty of monitoring the condition and preventing the breakdown of engineering equipment, networks and, especially, underground utilities. The solution of such particular problems corresponds to the concept of creating smart cities, but requires not only the collection of a large amount of information and, the installation of monitoring devices, but also a decision-making system for the purpose of work planning and financing. To solve such problems in world practice, NB-IoT (Narrow Band Internet of Things) technologies are already widely used as a system of interconnected digital devices within a single information space.

In principle, the concept of a "smart city" is synchronized with the concept of a digital economy, which is aimed at ensuring the effectiveness of all areas and processes through the use of information technology.

The digital economy is possible in the presence of three components:

- environment in which conditions can be created for the development of highly effective information technologies;

- digital platform;

- property complex objects or sectors of the economy (markets) in which service providers and consumers interact.

The formation of an environment adequate to digitalization takes place not only within the boundaries of regulatory and legislative content requiring information security, but also involves the use of a large amount of data.

The digitalization process in the housing and utility sector is also impossible without the availability of platforms, appropriate infrastructure, and technologies. The digital platform is a new business model, the essence of which is to provide business and the public with a specific service for coordinating the work and processes of different market participants. The functioning of various platforms provides market entities with a number of benefits, automatically creates trust ratings between them, and, which is the most important, it allows process participants and service consumers to identify themselves and instantly find each other. To digitalize processes in the housing sector, platforms are needed that combine municipal services, the population and various professional market participants, providing production, transportation of resources, the provision of repair and sanitary services, removal of household waste and other organizations.

In the presence of diverse scientific approaches and practices, it is an unambiguous fact that the implementation of the Smart City concept is based on relevant information, and it is the adequate management of the data array that can allow municipal services to improve the quality of life of the population, provide energy saving, and simplify the process of interaction with service consumers.

The data preparation in each particular case should fit the task at hand and take into account the features of the city structure and the specific conditions of the provided housing and communal services.

As it was already noted, the problem area in the structure of the housing and communal services of the city is the planning and organization of capital repairs, especially in conditions of limited funding. In order to solve this problem, an informational and analytical system of 
management and quality control of the overhaul of the housing stock can be formed. For the efficient functioning of the proposed system, it must provide the necessary data on the composition, condition of the housing stock, and the work actually performed, ensuring safe and comfortable living for people.

As an example, we cite the composition of the data necessary for the development of an informational and analytical system for managing and controlling the quality of overhaul in the framework of the Smart City concept. The recommended data set for the creation and functioning of such an informational and analytical system for monitoring the quality of capital repairs of the housing stock is presented below:

1. Complete list of the dwelling objects, including their location in a certain district of the city and precise address.

2. The year it was built and the durability classification.

3. Building type (brick, monolithic, prefabricated block building, pre-engineered, etc.).

4. Description of the main structural elements: type of roof and ceiling (attic, flat roof, etc.), type of enclosing structures (insulation, ventilated facade, etc.), technical data on engineering equipment and power supply networks, lighting, water supply, sanitation, the presence of a garbage chute, etc.

5. Presence and description of the lifting equipment, lift inspection period.

6. Schedule and standard periods for overhauls.

7. Actual overhaul period (if done).

8. Description of the performed works and overhaul quality assessment based on the documents signed by the residents.

9. Special conditions for operating the house during the inter-overhaul period (including accident rate, preventive maintenance, replacement of engineering equipment, modernization of built-in, rented premises, etc.).

10. Other information: list of residents, form of the housing administration, finance sources, composition of the minor repair works, etc.

Creation of a database containing this relevant information and the functioning of the informational and analytical management system will allow developing or optimizing overhaul plans, and conducting analysis will help building a system for effective monitoring of compliance with the deadlines and quality of capital repairs. For the functioning of the proposed system at the initial stage, the existing software package for the inventory of stationary objects can be adapted, which is used to automate the activities of the municipality administration to conduct an inventory of courtyards and public areas. This software is a system consisting of a mobile application that allows of accumulation of the information about an object and provides synchronization with the national information systems and a Web portal with an administration function.

\section{Results}

Information technologies are actively being introduced into the sphere of municipal services, while creating an integrated space that is as comfortable as possible for residents through the digitalization of the main housing and communal services systems. The creation of an informational and analytical system for managing and controlling the quality of the overhaul of the housing stock will allow accumulating reliable information about residential real estate objects and their parameters, identifying urgent repair objects, saving financial resources, and making the housing and public utilities and municipal improvement work more transparent.

\section{Conclusions}


The digital transformation of cities in their ability to provide a decent standard of living for the population should be determined not so much by the saturation of individual technological solutions of the "smart city" as by the quality and reasonableness of their choice and implementation. The main task of the comprehensive creation of a "smart city" should be a reasonable choice of solutions and technologies that optimally correspond to the plans and problems of the city's development. The need to take into account many interrelated factors makes it multi-criteria and non-trivial. System management of information technology implementation processes in the city is currently an unresolved task, both in the Russian Federation and around the world, due to the increasing complexity of the projects proposed for implementation. That is why the use of modern information technologies for the description, systematization, and modeling of urban elements and processes embodied in the digital image of a "smart city" becomes an important tool for improving the efficiency of city management and the formation of a high-quality and accessible urban environment.

\section{References}

1. Decree of the President of the Russian Federation of may 9, 203 "On The strategy for the development of the information society in the Russian Federation for 2017-2030" (2017) https://www.garant.ru/products/ipo/prime/doc/71570570/ (Last accessed 12.10.2020)

2. National program "Digital economy of the Russian Federation". https://digital.gov.ru/uploaded/files/natsionalnaya-programma-tsifrovaya-ekonomikarossijskoj-federatsii_NcN2nOO.pdf, (Last accessed 13.10.2020)

3. Monitoring of regional legislation in the field of digital economy development in the AIRR regions http://i-regions.org/images/files/monitoring-regionalnogozakonodatelstva.pdf, last accessed 2020/10/05 (Last accessed 14.10.2020)

4. 37 Russian cities will become pilot sites for the Smart city project https://tass.ru/ekonomika/5678813?amp (Last accessed 14.10.2020)

5. Smart cities http://www.tadviser.ru/index.php/ (Smart_cities) (Last accessed 14.10.2020)

6. S. A. Ayvazyan, M. Yu. Afanasiev, A. V. Kudrov, Indicators of regional development in the basis of differentiation characteristics http://digital-economy.ru/stati/indikatoryregionalnogo-razvitiya-v-bazise-kharakteristik-differentsiatsii (Last accessed 14.10.2020)

7. R. V. Dushkin, A. A. Esetov, S. D. Seitkazinov, D. A. Donetsk, Localities as intellectual agents: from smart to cognitive cities http://digital-economy.ru/stati/naseljonnyepunkty-kak-intellektualnye-agenty-ot-umnykh-k-kognitivnym-gorodam (Last accessed 15.10.2020)

8. S. I. Lutsenko, international experience in the development of smart cities: overview http://digital-economy.ru/obzory/mezhdunarodnyj-opyt-razvitiya-umnykh-gorodovobzor (Last accessed 15.10.2020)

9. O. E. Akimova, S. K. Volkov, Analysis of the features of the implementation of the concept of "Smart City" in the economic and economic practice of foreign countries. Problems of the modern economy, 3(71), 259-263 (2019)

10. O. N. Dolinina, V. V. Pechenkin, On the approach to managing household waste collection using the hybrid intelligent system of the Smart City project, Software systems and computational methods, 3, 1-15 (2017) 
11. A. A. Kulik, A. S. Ivashchuk, The Smart City model as the main trend in the transformation of cities in the context of digitalization, Materials of the All-Russian Scientific and Practical Conference "The Modern Paradigm and Mechanisms of Economic Growth of the Russian Economy and Its Regions”, 183-190 (2019)

12. O. V. Maksimchuk, Energy-efficient modernization of Russian cities based on the concept of "smart city", Sociology of the city, 3, 63-82 (2018)

13. A. E. Malyshev, The main directions of creating smart cities in the digital economy, Scientific and practical conferences with the participation of RSVM "Development of the economy and management in the context of digitalization. under the editorship of, 160-164 (2018)

14. A. Meijer, M. P. R. Bolı'var, Governing the smart city: a review of the literature on smart urban governance https://journals.sagepub.com/doi/pdf/10.1177/ 0020852314564308, last accessed 2020/10/05 (Last accessed 16.10.2020)

15. D. E. Namiot, V. P. Kupriyanovsky, S. A. Sinyagov, info-communication services in a smart city // International Journal of Open Information Technologies, 4(4), 1-9 (2016)

16. A. B. Pratama, Smart city narrative in Indonesia: comparing policy documents in four cities. Issues of State and Municipal Administration, 6, 65-83 (2018)

17. N. Romanova, N. Anisimova, I. Provotorov, Application of budgeting tools to cut structural imbalances in regional developmentmatec Web of Conferences Siberian Transport Forum - TransSiberia, 08017 (2018)

18. J. Simon, F. Sengers, F. Caprotti, Y. Dayot, The Smart City as Global Discourse: Storylines and Critical Junctures across 27 Cities https://www.tandfonline.com/doi/full/10.1080/10630732.2018.1558387 (Last accessed 16.10.2020)

19. A. A. Sharova, The Smart City project as a comprehensive solution to improve the quality of city management and the standard of living in them, Meridian, 14(32), 3-5 (2019)

20. E. A. Shnyrenkov, Economic problems of the development of the Smart City project in Russian cities, Economics and Entrepreneurship, 4(105), 304-307 (2019)

21. T. Smotrova, T. S. Narolina, T. A. Nekrasova, Digital platforms as a tool for transforming the economy. 7th international conference on education and social sciences. Abstracts \& Proceedings, 97-101 (2020)

22. A. V. Tebekin, A. A. Egorova, The solution of social problems of cities with the help of Smart City technology: problems and prospects, Journal of Sociological Research, 4(4), 32-46 (2019)

23. Yu. I. Treschevsky, M. V. Litovkin, S. N. Papin, E. O. Penina, The implementation model of the concept of "Smart city for active people" in the city of Voronezh, Collection of scientific articles of the International scientific-practical conference "Structural transformations of the economy of the territories: in the search for social and economic equilibrium”. In 2 volumes, 246-257 (2018)

24. L. Vidiasovaa, P. Kachurina, F. Cronembergerb, Smart Cities Prospects from the Results of the World Practice Expert Benchmarking. https://reader.elsevier.com/reader/sd/pii/S1877050917323955?token=37B1DFF654B5 C080D10C217282F6DF78158798C275D5B548B701248B99C2D38D434C1D5BAD3 C44822E04E5E1D799E0B4 (Last accessed 16.10.2020)

25. The Ministry of construction of Russia presented the first IQ index of cities https://www.minstroyrf.ru/press/minstroy-rossii-predstavil-pervyy-indeks-iq-gorodov/, last accessed 2020/10/05.A (Last accessed 16.10.2020) 